\title{
QUNEGEO
}

International Journal of Environment and Geoinformatics (IJEGEO) is an international, multidisciplinary, peer reviewed, open access journal.

\section{Population structure of Pagellus acarne (Risso, 1927) in the North Aegean Sea}

\section{Güzin GÜL, Ali İŞMEN, Mukadder ARSLAN İHSANOĞLU}

\section{Chief in Editor}

Prof. Dr. Cem Gazioğlu

\section{Co-Editors}

Prof. Dr. Dursun Zafer Şeker, Prof. Dr. Şinasi Kaya,

Prof. Dr. Ayşegül Tanık and Assist. Prof. Dr. Volkan Demir

Editorial Committee (March 2021)

Assoc. Prof. Dr. Abdullah Aksu (TR), Assit. Prof. Dr. Uğur Algancı (TR), Prof. Dr. Bedri Alpar (TR), Assoc. Prof. Dr. Aslı Aslan (US), Prof. Dr. Levent Bat (TR), Prof. Dr. Paul Bates (UK), İrşad Bayırhan (TR), Prof. Dr. Bülent Bayram (TR), Prof. Dr. Luis M. Botana (ES), Prof. Dr. Nuray Çağlar (TR), Prof. Dr. Sukanta Dash (IN), Dr. Soofia T. Elias (UK), Prof. Dr. A. Evren Erginal (TR), Assoc. Prof. Dr. Cüneyt Erenoğlu (TR), Dr. Dieter Fritsch (DE), Prof. Dr. Çiğgem Göksel (TR), Prof.Dr. Lena Halounova (CZ), Prof. Dr. Manik Kalubarme (IN), Dr. Hakan Kaya (TR), Assist. Prof. Dr. Serkan Kükrer (TR), Assoc. Prof. Dr. Maged Marghany (MY), Prof. Dr. Michael Meadows (ZA), Prof. Dr. Nebiye Musaoğlu (TR), Prof. Dr. Masafumi Nakagawa (JP), Prof. Dr. Hasan Özdemir (TR), Prof. Dr. Chryssy Potsiou (GR), Prof. Dr. Erol Sarı (TR), Prof. Dr. Maria Paradiso (IT), Prof. Dr. Petros Patias (GR), Prof. Dr. Elif Sertel (TR), Prof. Dr. Nüket Sivri (TR), Prof. Dr. Füsun Balık Şanlı (TR), Prof. Dr. Uğur Şanlı (TR), Duygu Ülker (TR), Prof. Dr. Seyfettin Taş (TR), Assoc. Prof. Dr. Ömer Suat Taşkın (TR), Assist. Prof. Dr. Tuba Ünsal (TR), Dr. Manousos Valyrakis (UK), Dr. İnese Varna (LV), Dr. Petra Visser (NL), Prof. Dr. Selma Ünlü (TR), Assoc. Prof. Dr. Oral Yağcı (TR), Prof. Dr. Murat Yakar (TR), Assoc. Prof. Dr. İ. Noyan Yılmaz (AU); Assit. Prof. Dr. Sibel Zeki (TR) 


\title{
Population structure of Pagellus acarne (Risso, 1927) in the North Aegean Sea
}

\author{
Güzin Güll,* iD , Ali İşmen² (iD, Mukadder Arslan İhsanoğlu² iD \\ ${ }^{1}$ Istanbul University, Institute of Marine Sciences and Management, Istanbul/Turkey \\ ${ }^{2}$ Çanakkale 18 March University, Faculty of Marine Sciences and Technology, Çanakkale/Turkey \\ Corresponding Author: G. Gül \\ E-mail: guzngul@gmail.com
}

Received: 28 Sep 2020

Accepted: 16 Nov 2020

How to cite: Gül et al. (2021). Population structure of Pagellus acarne (Risso, 1927) in the North Aegean Sea. International Journal

of Environment and Geoinformatics (IJEGEO), 8(1):019-027. doi: 10.30897/ijegeo.800936

\begin{abstract}
Sparidae family is one of the most important demersal group for Turkish fisheries. When considering the importance of Turkey fisheries, population parameters of Pagellus acarne Risso, 1827 give basic information for future fisheries studies. Studies of biology and population parameters of this species are very limited in the Aegean Sea; therefore we aimed to determine population parameters (length-weight relationship, age and growth parameters, mortality rates and, reproductive season) in order to obtain data for the future studies. We caught 2673 Pagellus acarne specimens between September 2006 to September 2008 from monthly samples at depths ranging from 20 to $500 \mathrm{~m}$ in the Saros Bay using a commercial bottom trawl net. Total length and weight range from 3.5 to $27.1 \mathrm{~cm}, 1.93$ to $314.5 \mathrm{~g}$, mean length and weight were $14.0 \pm 0.05 \mathrm{~cm}, 35.6 \pm 0.46 \mathrm{~g}$ respectively. The length-weight relationship was detected $\mathrm{W}=0.001 * \mathrm{~L} 3.054$, which indicated positive allometric growth. The high GSI value was in September. The data on maturity stages indicated that length at $50 \%$ maturity (L50) for females $18.1 \mathrm{~cm}$ TL for males $15.3 \mathrm{~cm}$ TL. The age data derived from sagitta otoliths reading were used to estimate the growth parameters and ranged from 1-4 aged. The von Bertalanffy growth parameters of the total were $\mathrm{L} \infty=30.63 \mathrm{~cm}, \mathrm{~K}=0.26$ year -1 , to $=-0.95$. The instantaneous total mortality was $\mathrm{Z}=0.72$ year- 1 , the natural mortality $\mathrm{M}$ $=0.54$ year -1 , the fishing mortality $\mathrm{F}=0.19$ year- 1 respectively. The exploitation ratio (E) of the stock was found as 0.26 . Pagellus acarne is the most important marine fish species with high commercial value for both the Turkey coast and the Mediterranean basin. This study aims to define basic population parameters which should be needed for further fisheries studies and management strategies in Saros Bay, the North Aegean Sea.
\end{abstract}

Keywords: North Aegean Sea, Pagellus acarne (Risso, 1927), Length at Maturity, Reproduction, Mortality

\section{Introduction}

Axillary seabream, Pagellus acarne Risso, 1827, a demersal fish belonging to the family Sparidae, is distributed along the European and African coasts of the Atlantic Ocean and in the Mediterranean including the Black Sea (Bauchot and Hureau 1986). This species can be found in diverse bottom types, particularly seagrass beds, down to the depth of $500 \mathrm{~m}$, but is most frequent between $40 \mathrm{~m}$ and $100 \mathrm{~m}$ (Froese and Pauly 2020). The species is mainly carnivorous, and the important prey items are fish, Arthropoda, Mollusca, and Echinodermata (Morato et al., 2001, Fehri-Bedoui et al., 2009).

Pagellus acarne exhibits protandric hermaphroditism (Fischer et al., 1987, Arculeo et al., 2000, Dominguez 2000). The biology of this species has been reported in different regions of the Aegean Sea (Tosunoğlu et al., 1997, Soykan et al., 2015), and in the Greek waters (Stergiou et al., 1997). Several authors studied age, growth and reproductive biology of axillary seabream in the Mediterranean and Atlantic (Phân and Kompowski 1972, Andaloro 1982, Campillo 1992, Arculeo et al., 2000, Dominguez 2000, Pajuelo and Lorenzo 2000, Zoubi 2001, Coelho et al., 2005, Abecasis et al., 2008, Velasco et al., 2011, İlhan et al., 2018, Keddar et al., 2020, Di Maio et al., 2020).
Despite its commercial value and abundance along the Turkish coasts, there is a lack of information on population parameters of Pagellus acarne in the region which is to be known a particularly important fishery area due to its nutrient enrichment originated from several river inputs. Thus, the Saros bay was prohibited for commercial trawling in 1997 as a consequence of being subjected to overfishing until the 1990s (İşmen et al., 2010). In this study, we present age, von Bertalanffy growth parameters, reproduction season and, mortality rates of Pagellus acarne for the first time in the region in order to sustain preliminary information and basic population parameters which should be needed for further fisheries studies and management strategies in the in Saros Bay, the North Aegean Sea.

\section{Materials and methods}

Specimens of the Axillary seabream were collected at depths ranging from $20 \mathrm{~m}$ to $500 \mathrm{~m}$ in Saros Bay, North Aegean Sea monthly starting from September 2006 to September 2008. Samplings were carried out via using a commercial bottom trawl net. A total of 184 trawl operations took 30 minutes per each with 2.5 knots $^{-1}$ hauling speed (Figure. 1). 


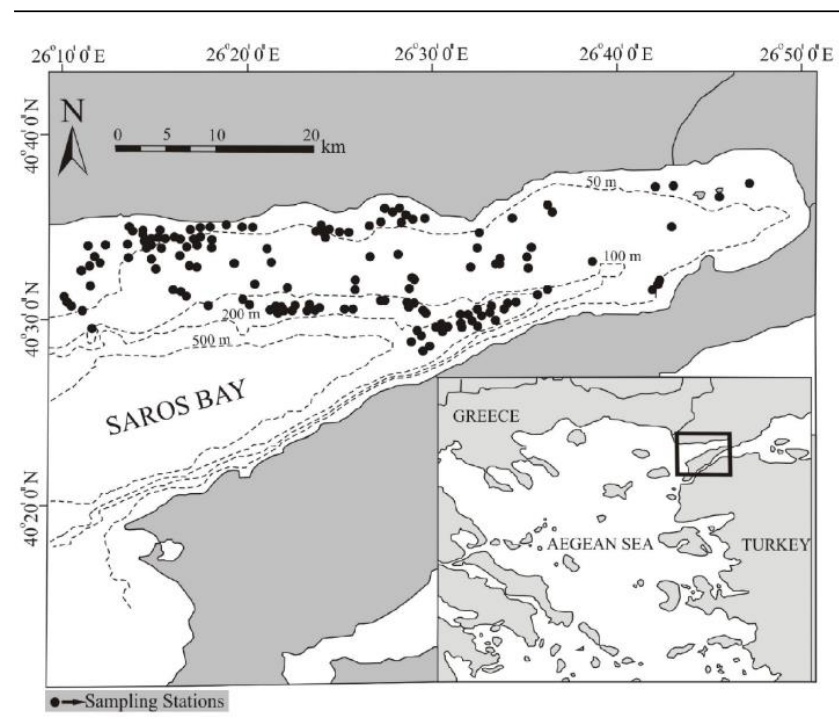

Figure 1. Sampling stations

Total length (TL) and total weight (TW) were measured to the nearest $0.1 \mathrm{~cm}$ and nearest $0.01 \mathrm{~g}$ respectively. The length-weight relationship was estimated with the formula: $\mathrm{W}=\mathrm{aL}^{\mathrm{b}}$; $\mathrm{a}$ and $\mathrm{b}$ of the exponential curve were estimated by linear regression analysis over logtransformed data $(\log \mathrm{W}=\log \mathrm{a}+\mathrm{b} \log \mathrm{L})$, where ' $\mathrm{W}$ ' is the total body weight $(\mathrm{g}), \mathrm{L}$ is the total length $(\mathrm{cm})$, ' $\mathrm{a}$ ' is the intercept and ' $b$ ' is the slope (Ricker 1975). Students' $t$-test was applied to evaluate whether the $\mathrm{b}$ value was significantly different from the isometric expected value of 3 (Pauly 1984).

During the study, the sex of 368 individuals was determined, and the reproductive season and length at $50 \%$ maturity $\left(\mathrm{L}_{50}\right)$ length were calculated. Gonad weight (WG) was determined to the nearest $0.01 \mathrm{~g}$, and the sex and maturity stage was determined macroscopically. The stage of maturation was classified according to Holden and Raitt, (1974) as follows; immature (I), maturing virgin and recovering spent (II), ripening (III), ripe (IV), spent (V). The spawning season was estimated following the monthly changes of gonadosomatic index (GSI) which was calculated according to Anderson and Gutreuter 1983 as follows: GSI $=100 W G \times W E^{-1}$ where $W G$ is the weight of the gonads, and $W E$ is the weight of eviscerated fish.

The sex ratio (male: female) was calculated, and a chisquare test was used to detect differences in the sex ratio. $\mathrm{L}_{50}$ was defined as the size of which $50 \%$ of the individuals considered as mature (stage III, stage IV). Specimens were grouped into $1 \mathrm{~cm}$ size classes, and the proportion of mature (stage III, stage IV) and immature individuals was calculated (Fontana, 1968). The percentages of mature individuals by length class and sex were fitted to a logistic function using Newton algorithm from Microsoft Excel solver routine: $F(L)=(1$ $+e-(\beta 0+\beta 1 L))$-were $\mathrm{F}(L)$ is the proportion of mature fish at length $L, \beta 0$ is the intercept and $\beta 1$ is the regression coefficient (Piñeiro and Saínza 2003). Age was estimated by counting the annual growth rings on sagitta otoliths which were placed in glycerine solution and examined under a binocular microscope at $10 \mathrm{x}$ with reflected lights against a dark background (Figure 2).
The von Bertalanffy growth parameters were estimated (von Bertalanffy 1938) according to the following equation: $\mathrm{Lt}=\mathrm{L}_{\infty}\left(1-\mathrm{e}^{\mathrm{K}}{ }_{0}^{\mathrm{K}(1-\mathrm{t})}\right)$ where $\mathrm{L}_{\mathrm{t}}$ is the length at age $t, L_{\infty}$ that the fish of a population would reach if they were to grow indefinitely, $\mathrm{K}$ is the growth coefficient and $t_{o}$ is the hypothetical age the fish would have had at zero-length (Froese and Pauly 2020). Growth parameters were estimated according to the non-linear method using the FISAT II (FAO-ICLARM Stock Assessment Tools) package (Sparre et al., 1989).

The total instantaneous mortality rates (Z) were calculated from the length-converted catch curve (Pauly, 1983) using program FiSAT II (Gayanilo et al., 1994).

Natural mortality (M) was calculated by Pauly's empirical equation (Pauly 1980):

$\log (M)=-0.0066-0.279 \log \left(L_{\infty}\right)+0.6543 \log (k)+$ $0.4634 \log (\mathrm{T})$ : where $\mathrm{M}=$ natural mortality, $\mathrm{L}_{\infty}$ and $\mathrm{K}=$ von Bertalanffy growth parameters, $\mathrm{T}=$ the mean annual temperature $\left(\mathrm{C}^{0}\right)$ which is assumed to reflect the local temperature (During this study we used the mean surface temperature via $\mathrm{CTD}, \mathrm{T}=14.1 \mathrm{C}^{0}$ ). The equation was calculated using the FISAT program (Gayanilo and Pauly, 1997). Fishing mortality rate (F) was estimated from the equation $\mathrm{F}=\mathrm{Z}-\mathrm{M}$ and exploitation of the stock rate $(E)$ from $E=F / Z$ (Sparre and Venema 1992).

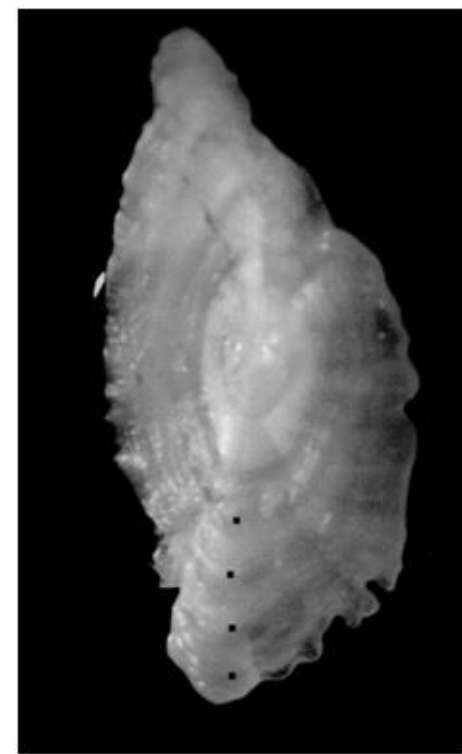

Figure 2. The right otholit of Pagellus acarne from North Aegean Sea

\section{Results}

A total of 2673 Pagellus acarne specimens were collected, ranging from 3.5 to $27.1 \mathrm{~cm}$. Among 368 sexually defined specimens; 246 (67\%), 117 (31\%), and $5(2 \%)$ of them were found as female-male and hermaphrodites respectively (Table 1).

A total of 2673 Pagellus acarne specimens were collected, ranging from 3.5 to $27.1 \mathrm{~cm}$. Among 368 sexually defined specimens; 246 (67\%), $117(31 \%)$, and $5(2 \%)$ of them were found as female-male and hermaphrodites respectively (Table 1). 
Table 1. Range and mean length and weight $( \pm \mathrm{SE})$ of Pagellus acarne from North Aegean Sea

\begin{tabular}{llllll}
\hline \multirow{2}{*}{ Sex } & \multirow{n}{*}{} & \multicolumn{2}{c}{ Total length } & \multicolumn{3}{c}{ Total weight } \\
\cline { 3 - 6 } & & Mean \pm SE $[\mathrm{cm}]$ & Range $[\mathrm{cm}]$ & Mean \pm SE $[\mathrm{g}]$ & Range [g] \\
\hline Female & 246 & $16.02 \pm 0.5$ & $11.8-27.1$ & $56.4 \pm 2.19$ & $17-314.5$ \\
Male & 117 & $16.7 \pm 0.27$ & $12-26.6$ & $66.2 \pm 3.89$ & $19.5-303.6$ \\
Hermaphrodite & 5 & $17.02 \pm 1.76$ & $14.4-19.1$ & $61.06 \pm 16.3$ & $38.16-77.14$ \\
Total & 2673 & $14.0 \pm 0.05$ & $3.5-27.1$ & $35.6 \pm 0.46$ & $1.9-314.5$ \\
\hline
\end{tabular}

$*_{n}=$ number of specimens, $S E=$ standard error.

Table 2. Length-weight relationship parameters for female and male Pagellus acarne from Saros Bay

\begin{tabular}{llllll} 
Sex & $\mathrm{n}$ & $\mathrm{a}$ & $\mathrm{b}$ & $\mathrm{R}^{2}$ & $p$ \\
\hline Female & 246 & 0.005 & $3.277 \pm 0.04$ & 0.95 & $p<0.05$ \\
Male & 115 & 0.004 & $3.364 \pm 0.07$ & 0.94 & $p<0.05$ \\
Total & 2673 & 0.001 & $3.054 \pm 0.01$ & 0.94 & $p<0.05$ \\
\hline
\end{tabular}

$*_{n}=$ number of spicemens, $a=$ intercept, $b=$ slope of the regression, $R^{2}=$ coefficient of determination, $p=$ significance level ( $t$-test).

The length distribution of axillary seabream indicated that the most frequent size class in females and males was the $16 \mathrm{~cm}$ length class (Figure 3). The sizefrequency distribution for males and females were not significantly different (Kolmogorov-Smirnov twosample test $p>0.05$ ). The overall sex ratio was $1: 2.1$ males to females and was significantly different from the expected 1:1 ratio $\left(p<0.05, X^{2}\right)$. According to the estimated $\mathrm{b}$ values, positive allometric growth was evident in all cases (t-test, $p<0.05$ ) (Table 2). The slopes of the regressions estimated for males and females did not differ $(p>0.05)$ (Figure 4).

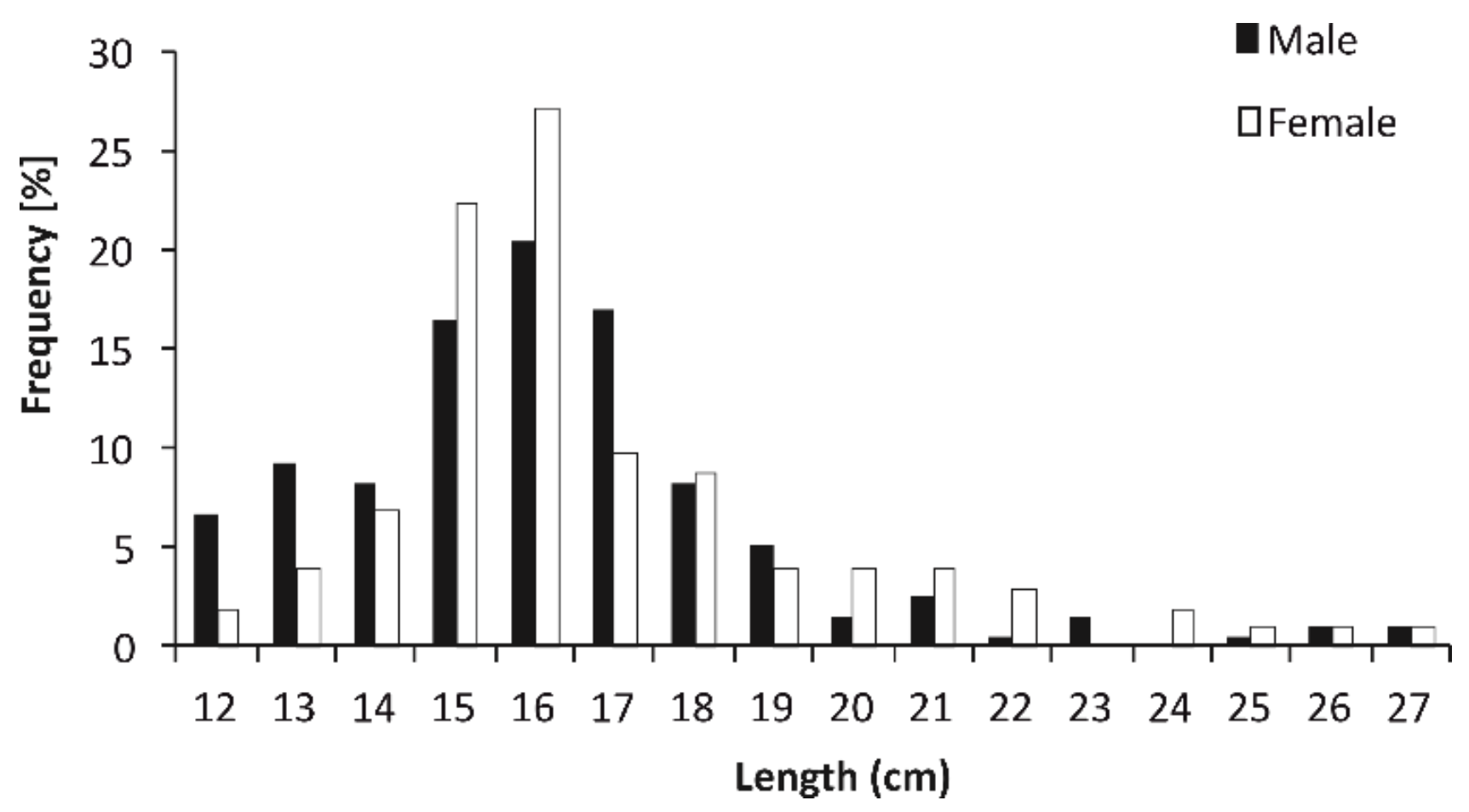

Figure 3. Length frequency distribution of Pagellus acarne from Saros Bay by sex. 

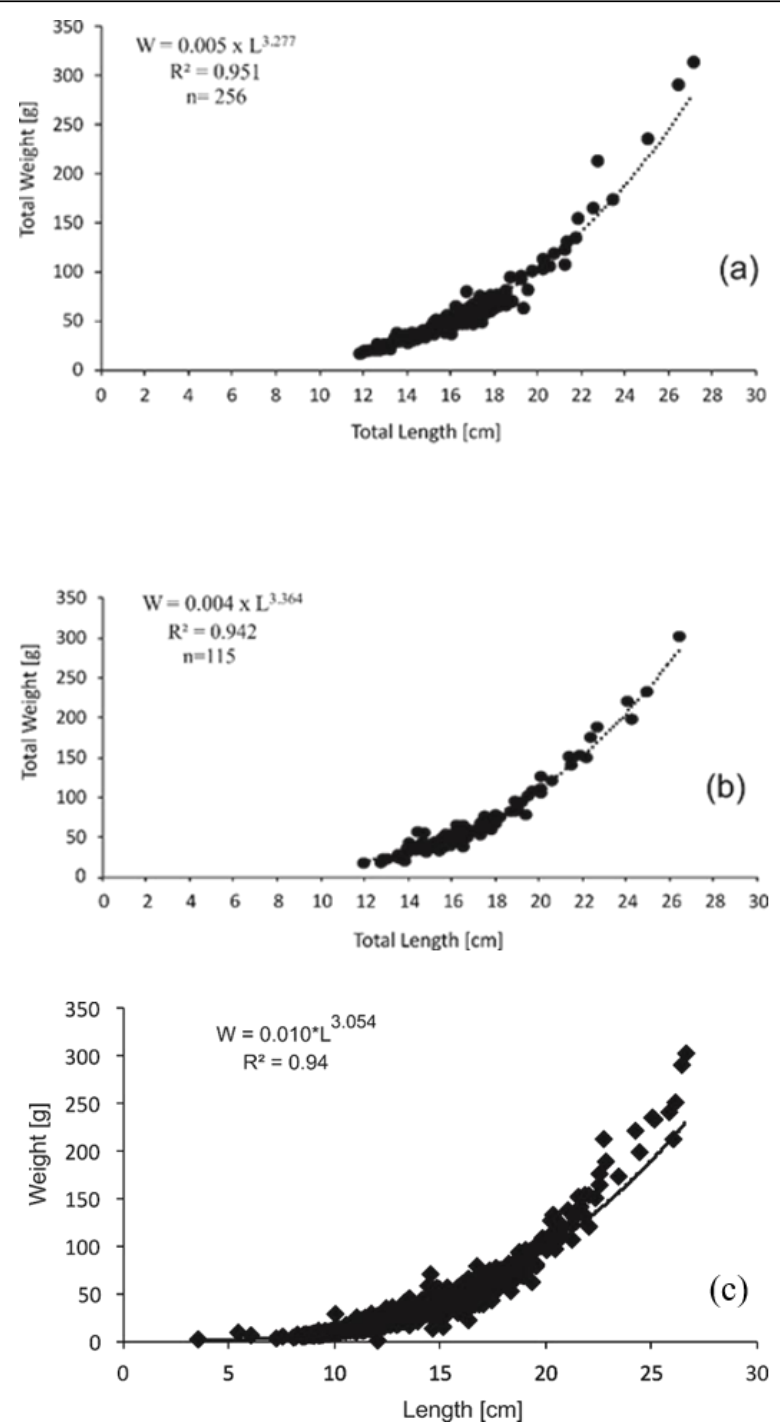

Figure 4. Length-weight relationship of Pagellus acarne from Saros Bay. ( a: female, b: male, c: total).

Females with mature gonads (stage III and stage IV) were recorded between August and November. Spent females (stage V) were recorded in September and November (Figure 5). GSI values declined sharply after September (Figure 6) and then started to increase slowly between November and April, followed by a rapid increase until August 2007. The same almost pattern was

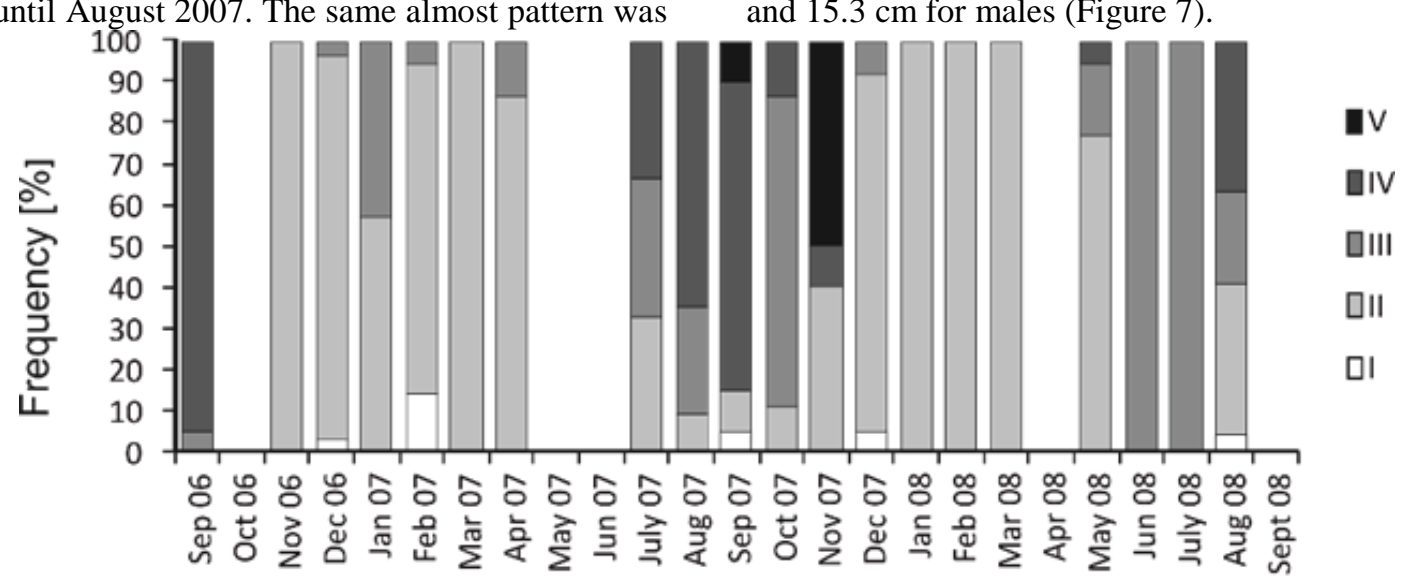

Month

Figure 5. Maturity stage frequency for females of Pagellus acarne from Saros Bay by month (I= immature, II= maturing virgin and recovering spent, $\mathrm{III}=$ ripening, $\mathrm{IV}=$ ripe, $\mathrm{V}=$ spent) followed in the next period. Monthly changes in the GSI suggest that gonad growth was remarkably high between August and September. The monthly variation of GSI and also maturity stages showed that the spawning period occurs between August and October. Size at maturity $\left(\mathrm{L}_{50}\right)$ was estimated to be $18.1 \mathrm{~cm}$ for females and $15.3 \mathrm{~cm}$ for males (Figure 7). 


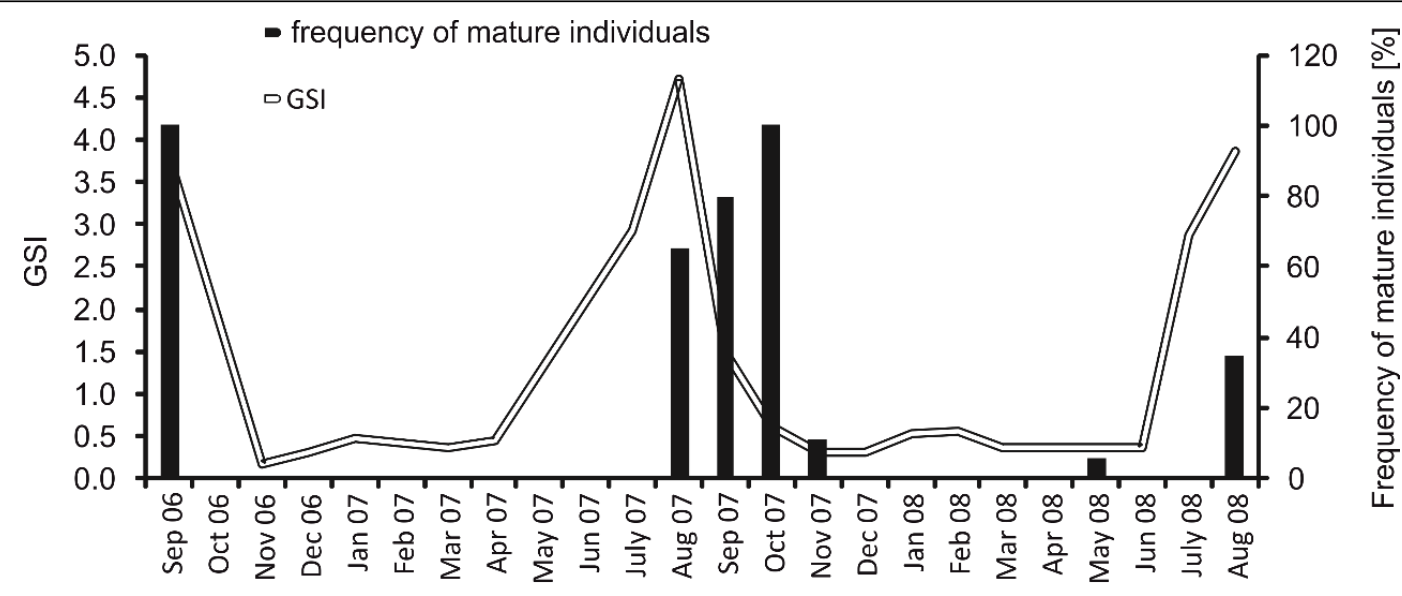

Months

Figure 6. Percentage of spawning individuals and gonadosomatic index (GSI) of female Pagellus acarne from North Aegean Sea by month.
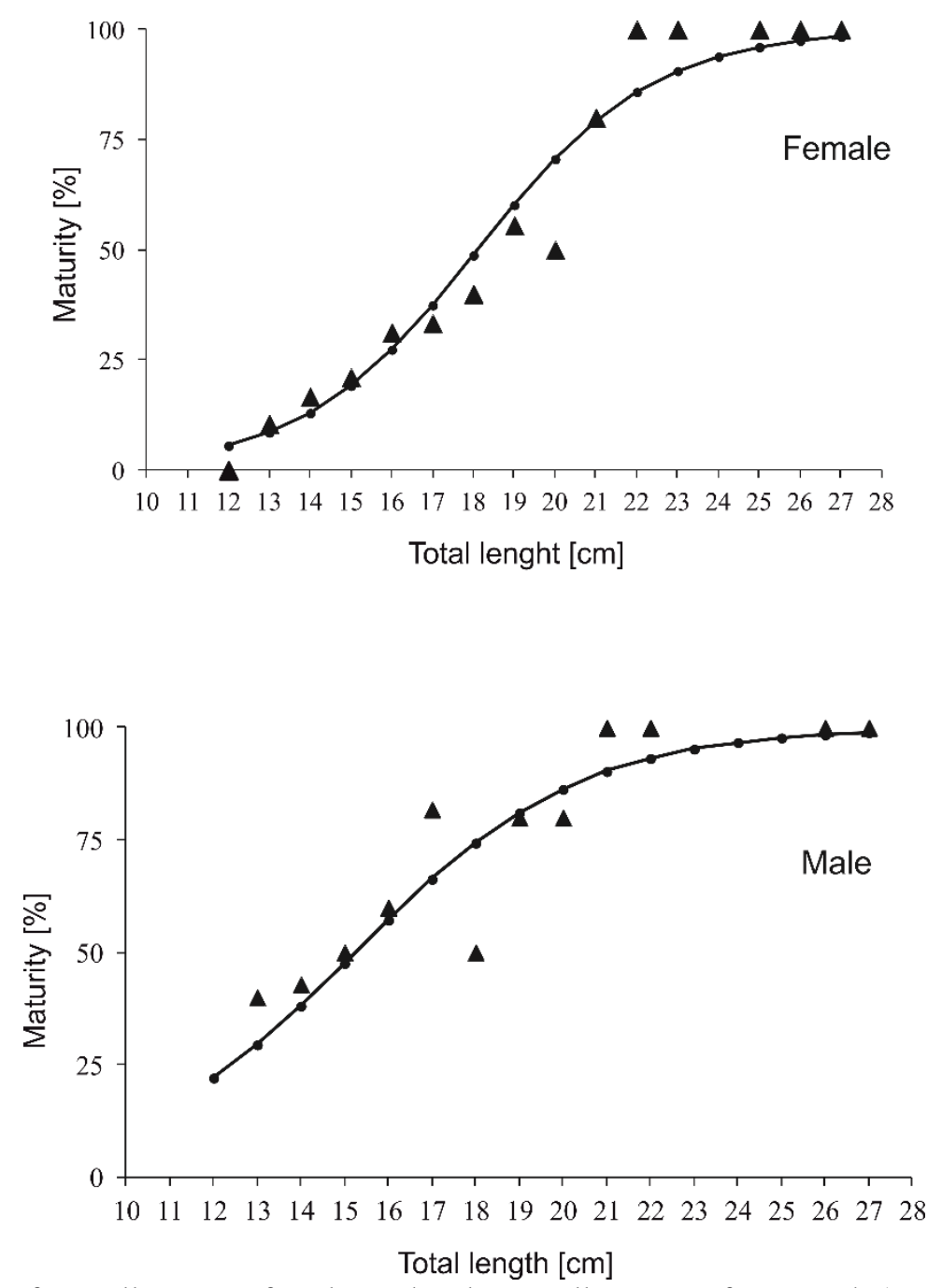

Figure 7. Percentage of sexually mature females and males Pagellus acarne from North Aegean Sea by size class.

Age was estimated for 194 specimens. Age ranged from 1 to 4 years. The dominant age group was 1 year (40\%), followed by age $2(42 \%)$, age $3(15 \%)$, and age $4(3 \%)$. Growth parameters which calculated with the von Bertalanffy equation were estimated as $\mathrm{L}_{\infty}=30.63 \mathrm{~cm}$, $\mathrm{K}=0.26$ year $^{-1}, \mathrm{t}_{\mathrm{o}}=-0.95$ year (Figure 9). The total length-otolith length relationship was calculated as follows: $\mathrm{OL}=0.305 \times \mathrm{TL}+1.421\left(\mathrm{R}^{2}=0.81\right)$.

The total mortality, $\mathrm{Z}$, were estimated at 0.72 year $^{-1}$ while natural and fishing mortality was calculated as $\mathrm{M}$ $=0.54$ year $^{-1}$ and $F=0.19$ year $^{-1}$, exploitation rate $(E)$ of stock was estimated to be 0.26 . 
Table 3. Growth parameters of Pagellus acarne from various geographic areas.

\begin{tabular}{|c|c|c|c|c|c|c|c|}
\hline Author & Location & Age & Sex & $\mathbf{L}_{\infty}$ & $\mathbf{K}$ & $t_{0}$ & $\varnothing$ \\
\hline Phân and Kompowski,1972 & Mauritania & - & - & 36.0 & 0.23 & -0.97 & 2.47 \\
\hline Andaloro, 1982 & Mediterranean & $1-8$ & - & 28 & 0.37 & - & 2.46 \\
\hline Mennes, $1985^{1}$ & Morocco & - & - & 31 & 0.21 & - & 2.3 \\
\hline Papaconstantinou et al.,, $1988^{1}$ & Ionian Sea & - & - & 32.1 & 0.17 & -1.67 & 2.23 \\
\hline Campillo 1992 & Italy & - & - & 28.0 & 0.37 & - & 2.46 \\
\hline Djbali et al.,, 1990 & Algeria & - & - & 24.4 & 0.3 & - & 2.25 \\
\hline Tosunoğlu et al.,, $1997^{1}$ & M. Aegean Sea & $1-3$ & - & 21 & 0.17 & -3.22 & 1.88 \\
\hline Pajuelo and Lorenzo, 2000 & Canary Island & $1-10$ & M & 30 & 0.27 & -0.67 & 2.39 \\
\hline Pajuelo and Lorenzo, 2000 & Canary Island & $1-10$ & $\mathrm{~F}$ & 33.9 & 0.21 & -0.99 & 2.38 \\
\hline Dominguez, 2000 & Alboran Sea & - & - & 29.62 & 0.27 & -1.36 & 2.39 \\
\hline Zoubi, 2001 & Morocco & - & - & 24 & 0.43 & -0.21 & 2.27 \\
\hline Coelho et al.,, 2005 & Portugal (South) & $1-18$ & - & 32.05 & 0.18 & -2.91 & 2.38 \\
\hline Coelho et al.,, 2005 & Portugal (South) & $1-13$ & M & 28.82 & 0.29 & -1.47 & 2.27 \\
\hline Coelho et al.,, 2005 & Portugal (South) & $1-18$ & $\mathrm{~F}$ & 32.3 & 0.18 & -2.56 & 2.29 \\
\hline Abecasis et al.,, 2008 & Portugal & $1-16$ & - & 31.84 & 0.19 & -2.86 & 2.20 \\
\hline Velasco et al.,, 2011 & Cadiz Bay & $1-7$ & - & 31.65 & 0.21 & -1.76 & 2.32 \\
\hline Velasco et al.,, 2012 & Alboran Sea & $1-7$ & - & 32 & 0.17 & -2.69 & 2.24 \\
\hline Soykan et al.,, 2015 & M. Aegean Sea & $1-6$ & - & 22.66 & 0.31 & -1.20 & 2.21 \\
\hline İlhan, 2018 & $\begin{array}{l}\text { Central Aegean } \\
\text { Sea }\end{array}$ & $1-4$ & - & 25.61 & 0.24 & -1.94 & - \\
\hline Keddar et al.,, 2020 & Mediterranean & - & - & 29.97 & 0.41 & -0.34 & 2.57 \\
\hline Present study & N. Aegean Sea & $1-4$ & - & 30.63 & 0.26 & 0.95 & 2.39 \\
\hline
\end{tabular}

${ }^{* 1}=$ based on fork length

\section{Discussion}

The maximum total length of Pagellus acarne in Saros Bay was determined as $27.1 \mathrm{~cm}$. Other studies in the Aegean Sea reported that maximum total length values were lower than the ones within the present study (Karachle and Stergiou 2008, Soykan et al., 2015) except for $62.2 \mathrm{~cm} \mathrm{TL}$ reported as the maximum in Greek waters (Moutopoulos and Stergiou 2000).

Both female and male Pagelus acarne exhibit positive allometric growth as previously reported for Mediterranean and Atlantic coast (Pajuelo and Lorenzo, 2000; Morey et al.,, 2003; Coelho et al., 2005; Ceyhan et al.,2009; Velasco et al., 2010; Soykan et al., 2015; İlhan 2018; Di Maio et al.,2020). On the contrary in the Aegean Sea, Moutopoulos and Stergiou (2002) found that negative allometry for Pagellus acarne in the Aegean Sea.

Axillary seabream displays protandric hermaphroditism as it had been reported (Alekseev 1967, Andolora 1982, Lamrini 1986, Buxton and Garratt 1990, Pajuelo and Lorenzo 2000, Di Maio et al 2020). The sex ratio of males to females calculated in the present study as 1:2.1 was similar to those reported in the studies published by Arculeo et al., (2000), Pajuelo and Lorenzo (2000) and Velasco et al., (2011) and Soykan et al., (2015). We observed that the female individuals within the same size group had outnumbered which supports the previous suggestion. Besides, according to Pajuelo and Lorenzo
(2000), Valesco et al., (2011), Di Maio et al., (2020) protandric hermaphroditism may explain the differences between females and males in the length-weight relationship; however, we did not find statistically significant differences in the length-weight relationship between males and females ( $p>0.05$ ). Also, Di Maio et al., (2020) calculated the length of sexual inversion as 22 $\mathrm{cm}$ TL of $P$. acarne in the Strait of Sicily, on the contrary, these results, we observed the $26.6 \mathrm{~cm}$ male specimens in the North Aegean Sea. It is important to obtain a piece of certain knowledge about the aspects of this species being protandric hermaphrodite; however, histological gonadal development data analysis was not performed in our study, the population of Pagellus acarne in the Northern Aegean Sea was not decisively classified as a protandric hermaphrodite species due to the inconsistency of our findings above. Reproductive season was observed in summer and autumn months. Spawning period appears to extend from August to October with a peak in September while resting period occurred mainly during the winter months. Previous studies support the present results of the reproductive season in this study (Andaloro 1982, Lamrini 1986, Santos et al., 1995, Arcuelo et al., 2000, Coelho et al., 2005, Velasco et al., 2011, Soykan et al., 2015; Di Maio et al., 2020). Phân and Kompowsky (1972) and Pajuelo and Lorenzo (2000) reported that the reproductive season was in winter and spring months in the Northwest African coasts and the Canary Islands, respectively. This difference could be derived by environmental factors, 
particularly temperature, which is crucially important for reproduction activities of fishes (Wootton 1990).

The value of $\mathrm{L}_{50}$ was evaluated as to be lower for males than for females. Based on the age results of the present study, males and females become sexually mature at the ages of 1 and 2, respectively. Pajuelo and Lorenzo (2000) reported $\mathrm{L}_{50}$ values as $15.8 \mathrm{~cm}$ for males (at the age of 2), and $19.4 \mathrm{~cm}$ for females (age of 3) in the Canary Islands. Coelho et al., (2005) found this values as 18.1 to 17.60 for males and females respectively in the south coast of Portugal, Lamrini (1986) indicated that $20.9 \mathrm{~cm}$ in the northwest Africa coast and lastly Soykan et al., (2015) determined the $\mathrm{L}_{50}$ values as $14.5 \mathrm{~cm}$ for females, $13.9 \mathrm{~cm}$ for males in the Central Aegean Sea.

Information about age is fundamental for estimating growth and mortality rates (Campana 2001). The estimation of the age of fishes is generally based on the counting of rings or marks on otoliths or scales (Campana and Neilson 1985, Morales-Nin 1992). The Axillary seabream has observable and interpretative otolith for age estimation (Erzini et al., 2001, Coelho et al., 2005, Abecasis et al., 2008 and Velasco et al., 2011). The oldest age recorded for Pagellus acarne was 18 years old in Portugal reported by Coelho et al., (2005). In the Aegean Sea, age composition of this species was reported by Tosunoğlu et al., (1997) as to be between 1-3 years and by Soykan et al., (2015) as to range between 16 years. The total length of fishes is linearly related to otolith length. Estimating the size of total length can be performed with fair reliability based on otolith length also, the otoliths which found in gut contexts of predators can be used to specify the fish species and to determine their size (Jobling and Breiby 1986, Wigley et al., 2003, Dietrich et al., 2006). Therefore, we determined otolith size of Pagellus acarne and relation with the total length in order to contribute a data for the further studies regarding this species. There is no data concerning the total length-otolith length relation in the Aegean Sea and the Mediterranean. However, Velasco et al., (2001) calculated the relationship between the total length and otolith radius in Southern Spain.

The results of previous studies about von Bertalanffy growth parameters performed in the Middle Aegean Sea for Pagellus acarne (Soykan et al., (2015): $\mathrm{L}_{\infty}=22.6$ and $\mathrm{K}=0.315$ year $^{-1} \mathrm{t}_{\mathrm{o}}=-1.20$ and Tosunoğlu et al., (1997): $\mathrm{L}_{\infty}=21 \mathrm{~cm}, \mathrm{~K}=0.17$ year $^{-1}$ and $\mathrm{t}_{\mathrm{o}}=-3.22$ ) differ from our growth findings, however, according to the Munro's phi-phrime test indicated that there were no significant differences between von Bertalanffy growth parameters of other studies $\left(\mathrm{t}_{\mathrm{s}}<\mathrm{t}_{\mathrm{t}}\right)$. Such differences can be originated because of depths of the sampling area which might affect the size distribution of individuals in catch also Table 4 indicates that the length range of the study abovementioned (Soykan et al., 2015) is narrow compared to our range.

A few studies about mortality rates of Pagellus acarne were performed in the middle Aegean Sea, Gurbet et al., (2012) reported that $Z=1.94$ year $^{-1}, M=0.68$ year $^{-1}$, $\mathrm{F}=1.26$ year $^{-1}$ and $\mathrm{E}=0.65$ while, Soykan et al., (2015) stated that $\mathrm{Z}=2.395$ year $^{-1}, \mathrm{M}=0.579$ year $^{-1}, \mathrm{~F}=1.816$ year $^{-1}$ and $E=0.758$. It is clear that these values are extremely higher than our mortality results which are total (Z), natural, fisheries and exploitation rate, respectively, in addition to this Pajuelo and Lorenzo (2000) presented mortality rates in the Canary Islands, $\mathrm{Z}=0.96$ year $^{-1}, \mathrm{M}=0.30$ year $^{-1}, \mathrm{~F}=0.66$ year $^{-1}$ and $\mathrm{E}=0.69$.

In conclusion, one of the most notable results of this study is the $\mathrm{L}_{50}$ value and the size-frequency distribution of the female specimens. Although we obtained similar results with the studies conducted in different regions of Mediterranean in terms of $\mathrm{L}_{50}$, we could not certainly confirm the protandric hermaphroditism of the North Aegean stocks for this species. This argument is based on our estimation of $\mathrm{L}_{50}$ value of female $P$. acarne that was smaller than the considered length of sex inversion according to the studies from Mediterranean. Besides, the differences in the von Bertalanffy growth parameters can be explained by the difference in length range which might be derived from different depth ranges of trawl operations. Saros Bay is a banned area for commercial fisheries activities; thus mortality rates, especially fisheries mortality and exploitation rate results, were consistent with the expected.

\section{Acknowledgements}

This study was financially supported by The Scientific and Technological Research Council of Turkey (TUBITAK) Project number: 106Y035. The authors would like to thank all the staff who helped both trawl survey in the laboratory.

\section{References}

Abecasis D., Bentes L., Coelho R., Correia C., Lino P.G., Monteiro P., Gonçalves J.M.S., Ribeiro J., Erzini K. (2008). Ageing seabreams: A comparative study between scales and otoliths. Fisheries Research 89: 37-48. DOI: 10.1016/j.fishres.2007.08.013.

Alekseev F.E. (1967). Hermaphroditism and regulation of population sexual structure in Pagellus acarne (Risso, 1826). ICES C.M 1967/G:7 and Hall, London, 264.

Andaloro F. (1982). Résume des paramètres biologiques sur Pagellus acarne de la mer Tyrrhénéenne méridionale et de la mer Lonienne Septentrionale. FAO Fisheries Report 266: 89-92 [In French].

Anderson R.O., Gutreuter S.J. (1983). Length, weight, and associated structural indices. In L. Nielsen and D. Johnson (eds.) Fisheries Techniques (pp. 284300). American Fisheries Society, Bethesda, Maryland.

Arculeo M., Brusle-Sicard S., Potoschi A., Riggio S. (2000). Investigations on gonadal maturation in Pagellus acarne (Pisces, Sparidae) in the Strait of Messina (Sicily). Italian Journal of Zoology, 67(4) 333-337. DOI: 10.1080/11250000009356335.

Bauchot M.L., Hureau J.C. (1986). Sparidae. in: Whitehead P.J.P, Bauchot M.L., Hureau J.C., Nielsen J., Tortonese E. (eds). Fishes of the North-eastern Atlantic and the Mediterranean (FNAM). Unesco, Paris. Vol. II: 883-907. 
Bauchot M.L., Hureau J.C., Miguel J.C. (1981). Sparidae. In: Fischer W., Bianchi G., Scott W.B. (eds) FAO species identification sheets for fishery purposes. Eastern Central Atlantic. (Fishing Areas 34, 47 (in part)). Vol. 4. FAO, Rome.

Buxton C. D., Garratt P. A. (1990). Alternative reproductive styles in seabreams (Pisces: Sparidae). Environmental Biology of Fishes, 28(1-4): 113-124. DOI: $10.1007 /$ BF00751031

Campana S. E., Neilson J.D. (1985). Microstructure of fish otoliths. Canadian Journal of Fisheries and Aquatic Sciences 42: 1014-1032. DOI: 10.1139/f85127.

Campana S.E. (2001). Accuracy, precision and quality control in age determination, including a review of the use and abuse of age validation methods. Journal of Fish Biology, 59: 197-242. DOI: 10.1111/j.10958649.2001.tb00127.x.

Campillo A. (1992). Les pêcheries françaises de Méditerranée: synthèse des connaissances Ifremer, France. 206 pp. [In French.]

Ceyhan T., Akyol O., Erdem M. (2009). Length-weight relationships of fishes from Gökova Bay, Turkey (Aegean Sea). Turkish Journal of Zoology, 33(1) :6972. DOI: 10.3906/zoo-0802-9.

Coelho R., Bentes L., Correia C., Goncalves J.M.S., Lino P.G., Monteiro P., Ribeiro J., Erzini K. (2005). Age, growth and reproduction of the axillary seabream, Pagellus acarne (Risso, 1827), from the south coast of Portugal. Thalassas 21: 79-84. DOI: 10.1590/S1679-87592010000300006.

Di Maio, F., Geraci, M. L., Scannella, D., Falsone, F., Colloca, F., Vitale, S., Fiorentino, F. (2020). Age structure of spawners of the axillary seabream, Pagellus acarne (Risso, 1827), in the central Mediterranean Sea (Strait of Sicily). Regional Studies in Marine Science, 34, 101082.

Dietrich J. P., Morrison, B. J., Hoyle, J. A. (2006). Alternative ecological pathways in the eastern Lake Ontario food web round goby in the diet of lake trout. Journal of Great Lakes Research, 32(2), 395-400.

Dominguez J.B. (2000). Biologia pesquera del besugo Pagellus acarne (Risso, 1826) del mar de Alboran: Fisheries biology of axillary seabream Pagellus acarne (Risso, 1826) in the Alboran Sea. Fuengirola (Malaga), Espana: Instituto Espanol de Oceanografia. [In Spanish].

Erzini K., Bentes L., Coelho R., Correia C., Lino P., Monteiro P., Ribeiro J., Gonçalves J.M.S. (2001). Fisheries biology and assessment of demersal species (Sparidae) from the south of Portugal. UE-DG XIV98/082. Final Report, 1-263.

Fehri-Bedoui R., Mokrani E., Ben Hassine O. K. (2009). Feeding habits of Pagellus acarne (Sparidae) in the Gulf of Tunis, central Mediterranean. Scientia Marina, 73(4), 667-678. DOI: 10.3989/scimar.2009.73n4667.

Fischer W., ML Bauchot et M. Schneider (rédacteurs) (1987). Fiches FAO d'identification des espèces pour les besoins de la Pêche (Révision I). Méditerranée et mer Noire Zone de pêche 37. Vol II. Vertébrés. Publication préparée par la FAO, résultat d'un accord ente la FAO et la Commission des Communautés
européenne(Projet GCP/INT/422/EEC) financé conjointement par ces deux organismes. Rome, FAO, 2: 761-1530. [In French]

Fontana A. (1968). Etude de la maturité sexuelle des sardinelles Sardinella Eba (Val) et Sardinella Aurita C. et V. de la région de Pointe-Noire. [In French].

Froese R., Pauly D. (eds). 2020. Fishbase World Wide Web electronic publication. www.fishbase.org, (10/2020).

Gayanilo J.R., Pauly D. (1997). FAO-ICLARM stock assessment tools Reference manual. Rome, ICLARM, International Center for Living Aquatic Resources Management. Food and Agriculture Organization of the United Nations.

Gurbet R., Akyol O., Yalcin E. (2012). Catch per Unit Effort and Mortality Rates of Two Sparid Species, Pagellus acarne and Pagellus erythrinus from Bottom Trawl Fishery in Izmir Bay, Aegean Sea. Journal of Animal and Veterinary Advances, 11: 681-686. DOI: 10.3923/javaa.2012.681.686

Holden M. J., Raitt D.F.S. (1974). Manual of fisheries science. Part 2-Methods of resource investigation and their application. FAO Fisheries Technical Report No. 115, Rev. 1:214

Ilhan, D. (2018). Age, Growth, And Diet Of Axillary Seabream, Pagellus Acarne (Actinopterygii: Perciformes: Sparidae), In The Central Aegean Sea. Acta Ichthyologica Et Piscatoria, 48(4).

İşmen A., Özekinci, U., Özen, Ö., Ayaz, A., Altınağaç, U., Yığın, Ç., Çakır, F. (2010). Saroz Körfezi (Kuzey Ege Denizi) Demersal Balıklarının Biyo-Ekolojisi Ve Populasyon Dinamiğinin Belirlenmesi. Pn: 106 YO35. Ankara. [In Turkish]

Jobling M., Breiby, A. (1986). The use and abuse of fish otoliths in studies of feeding habits ofmarine piscivores. Sarsia, 71(3-4), 265-274. DOI: 10.1080/00364827.1986.10419696.

Karachle P. K., Stergiou, K. I. (2008). Length-length and length-weight relationships of several fish species from the North Aegean Sea (Greece). Journal of Biological Research, 10, 149-157.

Lamrini A. (1986). Sexualité de Pagellus acarne (Risso, 1826) (Teleosteen Sparidae) de la côte Atlantique méridionale du Maroc $\left(21^{\circ}-26^{\circ} \mathrm{N}\right)$. Cybium, 10(1): 3-14. [In French].

Morales Nin B. (1992). Determination of Growth in bony fishes from otolith microstructure. FAO Fisheries Technical Paper 322. 51.

Morato T., Solà E., Grós M.P., Menezes G. (2001). Feeding habits of two congener species of seabreams, Pagellus bogaraveo and Pagellus acarne, off Azores (northeastern Atlantic) during spring of 1996 and 1997. Bulletin of Marine Science 69 (3): 1073-1087.

Moutopoulos D.K., Stergiou K.I. (2002). Length-weight and length-length relationships of fish species from the Aegean Sea (Greece). Journal of Applied Ichthyology 18 (3): 200-203. DOI: 10.1046/j.14390426.2002.00281.x.

Pajuelo J.G., Lorenzo J.M. (2000). Reproduction, age, mortality and growth of axillary seabream, Pagellus acarne (Sparidae), from the Canarian archipelago. Journal of Applied Ichthyology 16:41-47. DOI: 10.1046/j.1439-0426.2000.00154.x. 
Papaconstantinou C. (1988). Check-list of marine fishes of Greece. Fauna Graeciae IV, 257p.

Pauly D. (1980). On the interrelationships between natural mortality, growth parameters, and mean environmental temperature in 175 fish stocks. Journal du Conseil, 39(2): 175-192.

Pauly D. (1983). Some simple methods for the assessment of tropical fish stocks (No. 234). Food \& Agriculture Organization.

Pauly, D. (1984). Fish population dynamics in tropical waters: a manual for use with programmable calculators (Vol. 8). WorldFish.

Phân L.T., Kompowski A. (1972). The bronze bream, Pagellus acarne Risso from the north west African region. Acta Ichthyologica et Piscatoria. 2 (1): 1-18

Piñeiro C., Saínza, M. (2003). Age estimation, growth and maturityof the European hake (Merluccius merluccius (Linnaeus, 1758) from Iberian Atlantic waters. ICES Journal Marine Science 60: 10861102. DOI: 10.1016/S1054-3139(03)00086-9ps.

Ricker, W. E. (1975). Vital statistics from marking: single season experiments. Computation and Interpretation of Biological Statistics of Fish Populations. Fisheries Research Board of Canada, Bulletin, 191, 75-104.

Santos M., Montero C.C., Erzini K. (1995). Aspects of the biology and gillnet selectivity of the axillary seabream (Pagellus acarne, Risso) and common pandora (Pagellus erythrinus, Linnaeus) from the Algarve (South Portugal) Fisheries Research 23 (34): 223-236. DOI: 10.1016/0165-7836(94)00354-Y

Soykan O., İlkyaz A.T., Metin G., Kınacıgil H.T. (2015). Growth and reproduction of Boops boops, Dentex acrophthalmus, Diplodus vulgaris, and Pagellus acarne (Actinopterygii: Perciformes: Sparidae) rom east-central Aegean Sea, Turkey. Acta Ichthyologica et Piscatoria 45 (1): 39-55. DOI: 10.3750/AIP 2015.45.1.05

Sparre P., Venema S.C. (1992). Introduction to tropical fish stock assessment, Part 1-manual. FAO Fisheries technical paper 306-1 rev. 1. $376 \mathrm{p}$.

Sparre, P. Ursin. E., Venema, SC, 1989. Introduction to tropical fish stock assessment. Part 1. Manual. FAO Fish. Tech. Pap, 306, 1.

Stergiou K.I., Christou E.D., Georgopoulous D., Zenetos A., Souvermezoglou C. (1997). The Hellenic seas: physics, chemistry, biology and fisheries. In: Ansell A.D., Gibson R.N., Barnes M. (eds.) Oceanography and marine biology: an Annual Review Pp. 415-538. Aberdeen University Press, Aberdeen, Scotland

Tosunoğlu Z., Akyol O., Metin G., Tokaç A., Ünsal S. (1997). Gülbahçe körfezi'ndeki üç sparid türünün populasyon özelliklerinin araştırılması. [The study on the population characteristics of three sparid species in the Gülbahçe Bay.] Ege Üniveristesi Su Ürünleri Dergisi 14 (1-2): 127-143. [in Turkish.]

Velasco E.M., Jiménez Tenorio N., Del Arbol J., Bruzón M.A., Baro J., Sobrino I. (2011). Age, growth and reproduction of the axillary seabream, Pagellus acarne, in the Atlantic and Mediterranean waters offsouthern Spain. Journal of the Marine Biological Association of the United Kingdom 91 (6): 12431253. DOI: $10.1017 / \mathrm{S} 0025315410000305$.

Von Bertalanffy L. (1938). A quantitative theory of organic growth. Human Biology, 10:181-213.

Wigley S. E., McBride, H. M., \& McHugh, N. J. (2003). Length-weight relationships for 74 fish species collected during NEFSC research vessel bottom trawl surveys, 1992-99. NOAA Technical Memorandum nMFS-nE, 171, 36.

Wootton R. J. (1990). Ecology of Teleost Fishes. Chapman \& Hall, London.

Zoubi A. (2001). Etude de la biologie de croissance des principaux stocks démersaux de la Méditerranée marocaine. Rapport du Congrès de la Commission Internationale pour l'Exploration Scientifique de la Mer Méditerranée 36: 341-341 [in French] 